\title{
Translation Techniques in Environmentally Oriented Short Story Hinoki to Hinageshi (Pohon Hinoki dan Bunga Hinageshi) by Miyazawa Kenji into Indonesian
}

\author{
Dewi Kusmiati ${ }^{1 *}$, Lina Rosliana ${ }^{2}$, Elizabeth Ihan Rini ${ }^{3}$, and Zaki Ainul Fadli ${ }^{4}$ \\ ${ }^{1}$ Diponegoro University, Japanese and Culture Department, Semarang, Indonesia \\ ${ }^{2}$ Diponegoro University, Japanese and Culture Department, Semarang, Indonesia \\ ${ }^{3}$ Diponegoro University, Japanese and Culture Department, Semarang, Indonesia \\ ${ }^{4}$ Diponegoro University, Japanese and Culture Department, Semarang, Indonesia
}

\begin{abstract}
This study analyzed the translation techniques of Miyazawa Kenji's Hinoki to Hinageshi, which were translated to Indonesian as "Pohon Hinoki dan Bunga Hinageshi" by the UNPAD Press translation team. This short story tells about the life of a Hinoki tree with Hinageshi flowers that want to become a star, until one day a demon incarnates who wants to take advantage of Hinageshi flowers. In this short story, there are words that have a direct equivalent in Indonesian and those that do not have a direct word equivalent, so the aim of this study is to find the translation techniques used when translating this short story. The theory used is the theory of translation techniques by Hoed (2006), and data were collected using the literature review method. The collected data were analyzed with a distributional method. There are 7 types of translation techniques used by the translator: 1) Transposition, 2) Modulation, in the form of shifted meaning and a shift in the scope of meaning, 3) Descriptive Translation, 4) Contextual Conditioning, 5) Official/Standard Translation, and 6) Cultural Equivalent.
\end{abstract}

\section{Introduction}

Indonesian speakers enjoy not only Indonesian literary works but also literary works from abroad. One of the most popular is Japanese literature. However, for general readers to be able to enjoy Japanese literary works, translation products are needed. The translation product is a result of translation activities.

One of the previous studies regarding translation techniques was a study entitled Analysis of Translation Techniques and ill-formed Grammatical on AKB48 Song Lyrics by N.L.A.P. Utari, G.S. Hermawan, and I.W. Sadyana [1]. This study identifies the translation techniques applied in translating AKB48 song lyrics with Molina and Albir's (2002) theory with a syntactic approach and describes the grammatical flaws that occur in the translation results. The authors conclude that the translation technique that tends to be applied in translating AKB48 song lyrics is linguistic amplification. Its use is influenced by

* Corresponding author: dewkus318@gmail.com 
the lack of elements in Source Language (SL) that must be presented in Target Language (TL), so the translator must add a linguistic element. The ill-formed grammatical in the song lyrics translated from AKB48 to JKT48 is the slippage in word order, choice of word form, completeness of elements in each syntactic construction, use of function word, as well as the effectiveness of its structure

In this study, the author used data in the form of short stories by Miyazawa Kenji. The short stories by Miyazawa Kenji, which are compiled in a collection of Kaze no Matasaburo short stories, have themes related to the environment or nature. This is due to the educational background of Miyazawa Kenji, who is a bachelor of agriculture. The short story chosen by the author is entitled Hinoki to Hinageshi, or in Indonesian, it is translated as Pohon Hinoki dan Bunga Hinageshi. In the short story, there are several words that have a direct equivalent in Indonesian and words that do not have a direct equivalent in Indonesian. This short story also contains several words that can cause obstacles in the translation process, such as the ecological words hinoki and hinageshi. Therefore, the aim of this research is to find out what translation techniques the translator uses when translating Miyazawa Kenji's Hinoki to Hinageshi short stories.

\subsection{Translation}

According to Hoed (2006), translation is an effort to re-express messages contained in the text of a language or source text (SL/ST) into text in another language or target text (TL/TT) [2]. Translating consists of reproducing in the receptor language the closest natural equivalent of the source-language message, first in terms of meaning and secondly in terms of style [3]. Newmark (1988) explains that there are several levels in the translation process, 1) the textual level, 2) the referential level, 3) the cohesive level, and 4) the level of naturalness [4]. The textual level is when we intuitively and automatically convert the lexical units of the source language into the target language. The referential level is when we read a word or sentence, can we visualize it or what is imagined as something ambiguous. The cohesive level is an attempt to build feelings and emotions through value-laden or value-free expressions, which can determine the difference between a good translation and a boring or misleading translation. And the last is the level of naturalness which depends on the relationship between the writer and the reader and the topic or situation.

According to Nida (1966: 91) in Zulkarnaein (2018: 32), 5 cultural factors that cause obstacles when the translation process takes place are 1) ecology, namely different vocabulary, regarding climatic conditions, flora, fauna, etc.; 2) material culture, which is related to objects used in everyday life, 3 ) religious culture, namely the beliefs or beliefs held, 4) social factors, which involve all aspects of social structure, and 5) language factors used in society in that country [5]. For this reason, there are translation techniques as an effort that translators can do when experiencing these obstacles.

\subsection{Translation Techniques}

Translation techniques are ways of overcoming difficulties in translating at the level of words, sentences, or paragraphs [6]. Hoed divides these techniques into 9 types.

1. Transposition. The translator changes the sentence structure to get the correct translation. Example:

(a) He was unconscious when he arrived at the hospital.

(b) Ia sudah berada dalam keadaan tidak sadar saat tiba di rumah sakit.

(c) Setibanya di rumah sakit, ia sudah dalam keadaan tidak sadar.

(d) *Ia tidak sadar ketika tiba di rumah sakit. 
The translation results (b) and (c) are more acceptable than (d) even though the sentence structure is not parallel to (a). A transposition can also take the form of changing the structure of a long phrase or sentence to a short one.

2. Modulation. The translator provides an equivalent that is semantically different from the point of view of its meaning or scope of meaning, but in the context concerned gives the same message. Example:

(a) The laws of Germany govern this Agreement.

(b) Perjanjian ini diatur oleh hukum Jerman.

In the example above, there is a change from the active (a) to passive (b) point of view.

3. Descriptive Translation. The translator provides a description of the word whose equivalent is difficult to find or does not have an equivalent in TL.

(a) Licensed software.

(b) Perangkat lunak yang dilisensikan.

4. Contextual Conditioning. The translator provides additional explanations for certain words, usually those considered foreign by TL readers so that they are easier to understand.

(a) 桜はとてもきれいですね。

Sakura wa totemo kirei desune.

(b) Bunga Sakura sangat cantik, ya.

5. Footnotes. The translator provides long notes in the form of footnotes to clarify the meaning of the translated word.

6. Phonological translation. The translator could not find a suitable equivalent in TL so a new word was made which was taken from the sound of the word in SL to suit the sound system (phonology) and spelling (graphology). Example:

(a) Democratie (Dutch)

(b) Demokrasi.

7. Official/Standard Translation. This technique is carried out when there are terms, names, or expressions that are already exist in TL.

8. Not given an equivalent. The translator could not find the equivalent in TL, so for the time being, just quoted the word from SL.

9. Cultural Equivalent. The translator provides the equivalent in the form of cultural elements that are in TL. Example:

(a) "A" level exam (English)

(b) Ujian SPMB (New Student Admission Selection)

\section{Methods}

This research is a qualitative descriptive study. According to Bogdan and Taylor (1975: 5) in Muhammad (2014: 30) qualitative methodology is a research procedure that produces descriptive data in the form of written or spoken words from people and observable behavior [7]. Data were collected using the literature review/documentation method followed by notetaking techniques. The literature review/documentation method is a method that uses written sources to obtain data [8]. The data source in this study is the short story Hinoki to Hinageshi by Miyazawa Kenji. Furthermore, the data analysis method used is the distributional method with segmenting immediate constituents' techniques. The collected data were analyzed by dividing the lingual unit into several elements or parts. The results of the data analysis were presented using an informal presentation method, namely by using ordinary words. 


\section{Results and Discussion}

In this study, from 28 data, there are 7 types of techniques that were used in translating Hinoki to Hinageshi short stories, namely Transposition, Modulation, Descriptive Translation, Contextual Conditioning, Official/Standard Translation, Not given an equivalent, and Cultural Equivalent. The following is an example of data with different variations.

\subsection{Transposition}

Data 1

ST: めいめい風にぐらぐらゆれて、息もつけないようでした。[9]

Meimei/ kaze/ ni/ guragura/ yurete,/ iki/ mo/ tsukenai/ you deshita.

Masing-masing/ angin/ par/ berayun-ayun/ berayun/ napas/ par./ tidak dapat menghirup/ sepertinya.

TT: Tampaknya masing-masing tidak dapat bernafas sebab berayun-ayun ditiup angin. [10]

Data 1 is an example of the use of the transposition technique. In data 1, the sentence structure of TT is different from ST. This is due to differences in sentence structure in SL and TL. The SL sentence structure consists of Subject-Object-Predicate (S-O-P), while the TL sentence structure is Subject-Predicate-Object (S-P-O). In data 1, 風 に/ぐらぐら/ゆ れ $(\mathrm{S} / \mathrm{P})$ becomes "Berayun-ayun ditiup/ angin" $(\mathrm{P} / \mathrm{S})$ because it is a passive sentence and 息も/つけない $(\mathrm{O} / \mathrm{P})$ which its word for word meaning is "napas/ tidak dapat menghirup" becomes "tidak dapat bernafas". Sentences in data 1 were translated using transposition techniques because the sentence structure in Japanese (SL) is different from Indonesian (TL), so it must be adjusted to be acceptable with TL.

\subsection{Modulation}

Data 2

ST: ああつまらないつまらない、もう一生合唱手だわ。 [11]

Aa/ tsumaranai/ tsumaranai,/ mou/ isshou/ koorasu da wa.

Kata seru/ bosan/ bosan,/ kata seru/ selama hidup/ pengulangan lagu

TT: Aduh bosan! Sungguh bosan! Mungkin saya akan tinggal terus seperti ini sampai akhir hayat. [12]

In data 2 there is the word「合唱 手」 which means 'chorus'. If translated literally, the sentence becomes unacceptable "saya akan mengulang lagu selama hidup saya". Therefore, the translator uses modulation techniques to make the sentence easier to understand and acceptable in TL. The modulation technique in data 2 is a meaning shift modulation technique. Data 3

ST：しかし私はその先生の書生というでもありません。[13]

Shikashi/watashi/wa/ sono/sensei/ no/ shosei/ to iu/demo/ arimasen. Tetapi/ saya/ par/ itu/guru/ par/ murid/ bahwa/ pun/ bukan.

TT: Tapi saya kan bukan murid dari ibu ahli kecantikan itu. [14]

In data 3 , the word 「先生」 is translated as "ibu ahli kecantikan". The basic meaning of the word 'sensei' is teacher but it is also used as a nickname for people who are respected or people with certain professions, such as doctors, novelists, mangaka, and so on. The word 'sensei' in the above sentence refers to a salon owner in the story, but the gender is not known. The translator uses the modulation technique to shift the scope of meaning from broad to narrow, namely the netral gender word "teacher" to be a more specific "ibu ahli kecantikan" or "Mrs. Beautician". 


\subsection{Descriptive Translation}

Data 4

ST: それに全然無学だな。[15]

Sore ni/ zenzen/mugaku da na

Selain itu/ sama sekali/ buta huruf

TT: Lagi pula mereka rupanya sama sekali tidak mengenal sekolah. [16]

In data 4, the word 「無学」 does not have a direct equivalent in TL, but the meaning of the word is illiterate (due to not attending school) or uneducated. In order for the message of the sentence to be conveyed, the translator uses a description translation technique, so that the word 'mugaku' is translated as "tidak mengenal sekolah."

\subsection{Contextual Conditioning}

Data 5

ST: ひなげしはみんなまっ赤に然えあがり [17]

Hinageshi/wa/ minna/ makka/ ni/ moe agari

Hinageshi/ par/ semua/ merah terang/ par/ terbakar

TT: Bunga Hinageshi mekar semarak tinggi dengan warna merah menyala [18]

In data 5 there is the word 「ひなげし」, which is also found in the title. Hinageshi is a wild plant that is cultivated with the scientific name 'papaver rhoeas' or better known as 'common poppy'. The translator uses contextual conditioning technique because there is no direct equivalent in the TL, so it is necessary to add an explanation related to the word 'hinageshi'. The use of this technique is also a strategy to maintain the uniqueness of SL in TL.

\subsection{Official/Standard Translation}

Data 6

ST: ベートーベンの着たような青いフロックコートを着せて [19]

Beethoven/ no/ kita/ youna/ aoi/furokku kooto/ o/ kisete

Beethoven/ par/ pakai/ seperti/ biru/ jas mantel/ par/ mengenakan

TT: Dia mengenakan baju biru seperti apa yang dipakai oleh Beethoven. [20]

In data 6 , there is the word 「ベートーベン」 which is the name of a famous composer and pianist. Therefore, translators use official/standard translation techniques.

\subsection{Not Given an Equivalent}

Data 7

ST: お一人が五ビルです。[21]

O hitori/ ga/ go-biru desu.

Seorang/ par/ lima-biru.

TT: Per kepala sekitar lima bilu saja. [22]

Data 7 contains the word「五ビル」 which translates to "lima bilu". The word "bilu" in this sentence is difficult to translate because it does not exist in dictionary and is difficult to find on the internet. In addition, the writing that uses katakana letters further hinders the translator from finding the right equivalent. 


\subsection{Cultural Equivalent}

\section{Data 8}

ST: そしてキャベジと鮒とをな灰で者込んでおいてくれ。[23]

Soshite/ kyabetsu/ to/ funa/ to/ o/ nahai/ de/ nikonde oitekure.

Kemudian/ kol/ dan/ crucian carp/ par/ par/ abu/ rebuslah.

TT: Kemudian rebuslah kol dan ikan tawes dengan abu sampai matang. [24]

In data 8, the word 「鮒」 is translated as "tawes fish". The translator uses a cultural equivalent technique because in TL there is fish which is similar to 'funa'. The equivalent given by the translator is not quite right because "funa" is a crucian carp which in TL is known as "ikan mas", while "tawes fish" is a java barb. However, considering that "ikan mas" can also be interpreted as aquarium fish, the translator makes "tawes fish" as the equivalent of the word "funa" so that it is not ambiguous.

\section{Conclusion}

Based on the results of the research that has been done, the authors conclude that the translation techniques used by the translator in translating the Hinoki to Hinageshi short stories, which are translated into Indonesian as Pohon Hinoki dan Bunga Hinageshi are transposition, modulation in the form of shifted meaning and narrowing of meaning, descriptive translation, contextual conditioning, official/ standard translation, not given any equivalent and cultural equivalent. The techniques that tend to be used are transposition and modulation because of the differences in sentence construction in SL and TL.

Japanese literature is difficult for Japanese learners to understand. Moreover, works that are oriented to certain aspects, such as the collection of short stories Kaze no matasaburo by Miyazawa Kenji which are oriented to the environment and nature. The translation techniques that the writer found in the short story Hinoki to Hinageshi are used by the translator in accordance with the purpose of translation, namely for Japanese learners who find it difficult to understand Japanese literary works by thinking about word equivalent options that are close to TL, so that the author concludes that the short story and the results of the translation are in accordance with the purpose of the translation. This research is expected to increase readers' insight and inspire fellow Japanese learners who wish to explore this topic, especially Miyazawa Kenji's other works that are oriented towards the environment or nature.

\section{References}

1. N.L.A.P. Utari, G.S. Hermawan, I.W. Sadyana, JPBJ, 3, 166-178 (2017)

2. B.H. Hoed, Penerjemahan dan Kebudayaan, (Pustaka Jaya Jakarta, 2006)

3. E.A. Nida, C.R. Taber, The Theory and Practice of Translation, (E.J. Brill Leiden, 1982

4. P. Newmark, A Text Book of Translation, (Prentice Hall New York, 1988)

5. Z. Zulkarnaein, Penerjemahan Kesepadanan Pada Kosakata Fisik Bermuatan Budaya Materiil Bahasa Jepang ke Bahasa Indonesia dalam Novel Oda Nobunaga, B.A. thesis, Dept. Ja. Lang. and Cult., Diponegoro Univ., Semarang, (2018)

6. B.H. Hoed, Penerjemahan dan Kebudayaan, (Pustaka Jaya Jakarta, 2006)

7. Muhammad, Metode Penelitian Bahasa, (Ar-ruz Media Yogyakarta, 2014)

8. M. Zaim, Metode Penelitian Bahasa: Pendekatan Struktural, (Sukabina Press Padang, 2014) 
9. Y.Y. Risagarniwa, J. Johana, P.M. Kadir, R.L. Ardiati, H. Hikmatusadis, A. Saleha, I.I. Sidiq, P.Y. Ginanjar, Kaze no Matasaburo Kumpulan Cerita Pendek Karya Sastra Miyazawa Kenji, (Unpad Press Sumedang, 2020)

10. Y.Y. Risagarniwa, J. Johana, P.M. Kadir, R.L. Ardiati, H. Hikmatusadis, A. Saleha, I.I. Sidiq, P.Y. Ginanjar, Kaze no Matasaburo Kumpulan Cerita Pendek Karya Sastra Miyazawa Kenji, (Unpad Press Sumedang, 2020)

11. Y.Y. Risagarniwa, J. Johana, P.M. Kadir, R.L. Ardiati, H. Hikmatusadis, A. Saleha, I.I. Sidiq, P.Y. Ginanjar, Kaze no Matasaburo Kumpulan Cerita Pendek Karya Sastra Miyazawa Kenji, (Unpad Press Sumedang, 2020)

12. Y.Y. Risagarniwa, J. Johana, P.M. Kadir, R.L. Ardiati, H. Hikmatusadis, A. Saleha, I.I. Sidiq, P.Y. Ginanjar, Kaze no Matasaburo Kumpulan Cerita Pendek Karya Sastra Miyazawa Kenji, (Unpad Press Sumedang, 2020)

13. Y.Y. Risagarniwa, J. Johana, P.M. Kadir, R.L. Ardiati, H. Hikmatusadis, A. Saleha, I.I. Sidiq, P.Y. Ginanjar, Kaze no Matasaburo Kumpulan Cerita Pendek Karya Sastra Miyazawa Kenji, (Unpad Press Sumedang, 2020)

14. Y.Y. Risagarniwa, J. Johana, P.M. Kadir, R.L. Ardiati, H. Hikmatusadis, A. Saleha, I.I. Sidiq, P.Y. Ginanjar, Kaze no Matasaburo Kumpulan Cerita Pendek Karya Sastra Miyazawa Kenji, (Unpad Press Sumedang, 2020)

15. Y.Y. Risagarniwa, J. Johana, P.M. Kadir, R.L. Ardiati, H. Hikmatusadis, A. Saleha, I.I. Sidiq, P.Y. Ginanjar, Kaze no Matasaburo Kumpulan Cerita Pendek Karya Sastra Miyazawa Kenji, (Unpad Press Sumedang, 2020)

16. Y.Y. Risagarniwa, J. Johana, P.M. Kadir, R.L. Ardiati, H. Hikmatusadis, A. Saleha, I.I. Sidiq, P.Y. Ginanjar, Kaze no Matasaburo Kumpulan Cerita Pendek Karya Sastra Miyazawa Kenji, (Unpad Press Sumedang, 2020)

17. Y.Y. Risagarniwa, J. Johana, P.M. Kadir, R.L. Ardiati, H. Hikmatusadis, A. Saleha, I.I. Sidiq, P.Y. Ginanjar, Kaze no Matasaburo Kumpulan Cerita Pendek Karya Sastra Miyazawa Kenji, (Unpad Press Sumedang, 2020)

18. Y.Y. Risagarniwa, J. Johana, P.M. Kadir, R.L. Ardiati, H. Hikmatusadis, A. Saleha, I.I. Sidiq, P.Y. Ginanjar, Kaze no Matasaburo Kumpulan Cerita Pendek Karya Sastra Miyazawa Kenji, (Unpad Press Sumedang, 2020)

19. Y.Y. Risagarniwa, J. Johana, P.M. Kadir, R.L. Ardiati, H. Hikmatusadis, A. Saleha, I.I. Sidiq, P.Y. Ginanjar, Kaze no Matasaburo Kumpulan Cerita Pendek Karya Sastra Miyazawa Kenji, (Unpad Press Sumedang, 2020)

20. Y.Y. Risagarniwa, J. Johana, P.M. Kadir, R.L. Ardiati, H. Hikmatusadis, A. Saleha, I.I. Sidiq, P.Y. Ginanjar, Kaze no Matasaburo Kumpulan Cerita Pendek Karya Sastra Miyazawa Kenji, (Unpad Press Sumedang, 2020)

21. Y.Y. Risagarniwa, J. Johana, P.M. Kadir, R.L. Ardiati, H. Hikmatusadis, A. Saleha, I.I. Sidiq, P.Y. Ginanjar, Kaze no Matasaburo Kumpulan Cerita Pendek Karya Sastra Miyazawa Kenji, (Unpad Press Sumedang, 2020)

22. Y.Y. Risagarniwa, J. Johana, P.M. Kadir, R.L. Ardiati, H. Hikmatusadis, A. Saleha, I.I. Sidiq, P.Y. Ginanjar, Kaze no Matasaburo Kumpulan Cerita Pendek Karya Sastra Miyazawa Kenji, (Unpad Press Sumedang, 2020)

23. Y.Y. Risagarniwa, J. Johana, P.M. Kadir, R.L. Ardiati, H. Hikmatusadis, A. Saleha, I.I. Sidiq, P.Y. Ginanjar, Kaze no Matasaburo Kumpulan Cerita Pendek Karya Sastra Miyazawa Kenji, (Unpad Press Sumedang, 2020) 
24. Y.Y. Risagarniwa, J. Johana, P.M. Kadir, R.L. Ardiati, H. Hikmatusadis, A. Saleha, I.I. Sidiq, P.Y. Ginanjar, Kaze no Matasaburo Kumpulan Cerita Pendek Karya Sastra Miyazawa Kenji, (Unpad Press Sumedang, 2020) 